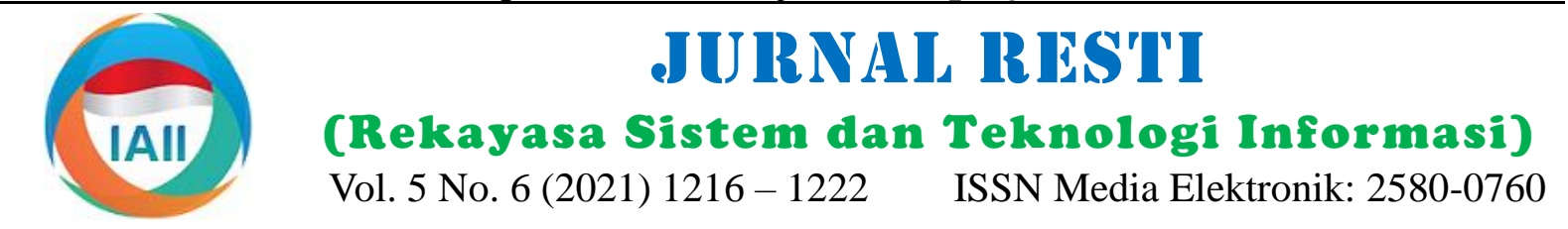

\title{
Klasifikasi Penyakit Padi berdasarkan Citra Daun Menggunakan Model Terlatih Resnet101
}

\author{
Ulfah Nur Oktaviana ${ }^{1}$, Ricky Hendrawan ${ }^{2}$, Alfian Dwi Khoirul Annas ${ }^{3}$, Galih Wasis Wicaksono ${ }^{4}$ \\ ${ }^{1}$ Informatika, Teknik, Universitas Muhammadiyah Malang \\ ${ }^{2}$ Informatika, Teknik, Universitas Muhammadiyah Malang \\ ${ }^{3}$ Agroekoteknologi, Peternakan dan Pertanian, Universitas Muhammadiyah Malang \\ ${ }^{4}$ Informatika, Teknik, Universitas Muhammadiyah Malang \\ 11ulfanuroktaviana575@webmail.umm.ac.id, ${ }^{2}$ ricky_hndrwn98@gmail.com*, ${ }^{3}$ alfiandwikhoirula033@gmail.com, \\ ${ }^{4}$ galih.w.w@umm.ac.id
}

\begin{abstract}
Rice is a staple food source for most countries in the world, including Indonesia. The problem of rice disease is a problem that is quite crucial and is experienced by many farmers. Approximately 200,000 - 300,000 tons per year the amount of rice attacked by pests in Indonesia. Considerable losses are caused by the disease of rice plants that are too late to be diagnosed so that they reach a severe stage and cause crop failure. Ignorance of farmers as well as limited and lack of information about diseases and proper treatment are factors that cause delays in handling rice diseases. Therefore, in this study the developed model can classify three types of rice plant diseases using Rice Leaf Disease images. The three types of disease include: Bacterial Leaf Blight, Brown Spot, and Leaf Smut. The model developed using the transfer learning method with a pretrained model of Resnet101 with additional architectural layer in the Fully Connected Layer section in the form of: Dense Layer, Dropout Layer, and Batch Normalization Layer. The proposed method shows a classification performance of 100\% on validation data, with a loss value of $5.61 \%$.
\end{abstract}

Keywords: Classification, Disease, Rice, Image, Pretrained model, ResNet101.

\begin{abstract}
Abstrak
Padi merupakan sumber makanan pokok bagi sebagian besar negara di dunia, termasuk Indonesia. Permasalahan penyakit padi merupakan masalah yang cukup krusial dan banyak dialami oleh petani. Sekitar 200.000 - 300.000 ton per tahun jumlah padi yang terserang hama di Indonesia. Kerugian yang cukup banyak diakibatkan oleh penyakit tanaman padi yang terlambat untuk didiagnosis sehingga mencapai tahap yang parah dan menyebabkan terjadinya gagal panen. Ketidaktahuan petani serta terbatas dan kurangnya informasi mengenai penyakit dan penanganan yang tepat menjadi faktor penyebab terlambatnya penanganan penyakit padi. Oleh karena itu, pada penelitian ini dikembangkan model yang dapat mengklasifikasikan tiga jenis penyakit tanaman padi dengan menggunakan citra Rice Leaf Disease. Ketiga jenis penyakit tersebut diantaranya: Bacterial Leaf Blight, Brown Spot, dan Leaf Smut. Model dikembangkan dengan menggunakan metode transfer learning dengan pretrained model Resnet101 dengan tambahan beberapa lapisan arsitekur pada bagian Fully Connected Layer berupa: Dense Layer, Dropout Layer, dan BatchNormalization Layer. Metode yang diusulkan menunjukkan performa klasifikasi sebesar $100 \%$ pada data validasi, dengan nilai loss sebesar 5,61\%.
\end{abstract}

Kata kunci: Klasifikasi, Penyakit, Padi, Citra, Pretrained model, ResNet101.

\section{Pendahuluan}

Sektor pertanian padi memegang peran penting dalam kontribusi ekonomi di Indonesia. Mengingat saat ini komoditas padi menjadi komoditas terbesar. Banyak negara yang yang menggunakan padi sebagai bahan makanan pokok utamanya tidak terkecuali Negara Indonesia. Fakta tersebut mengharuskan Indonesia untuk terus berinovasi sehingga ketersediaan padi melimpah dan tetap stabil [1]. Pertanian sendiri adalah kegiatan yang memanfaatkan alam untuk menghasilkan bahan pangan. Salah satu jenis pertanian adalah budidaya tanaman padi. Namun, banyak penyakit yang menyerang tanaman padi. Terdapat beberapa jenis penyakit pada tanaman padi seperti: penyakit hawar 
daun, penyakit blast, penyakit hawar pada batang, proses klasifikasi penyakit pada daun padi dengan penyakit kresek, dan lainnya. Masing-masing penyakit akurasi model sebesar 92,68\%. mengharuskan penanganan yang berbeda, jika hal tersebut terlambat untuk disadari dan tidak ditangani dengan benar maka dapat menyebabkan kerugian berupa gagal yang berimbas pada penurunan produksi tanaman padi itu sendiri [2], [3]. Dari 82 ribu desa yang berpotensi dikembangkan pertanian, hanya terdapat 73 ribu petugas penyuluh pertanian [4]. Oleh karena itu, terbatasnya penyuluh pertanian lapangan mengenai hama dan penyakit tanaman padi pada saat ini dinilai berdampak pada kurangnya informasi yang diperoleh oleh para petani mengenai hama dan penyakit tanaman padi. Kurangnya informasi mengenai hama dan penyakit tanaman padi berakibat juga pada penanganan maupun pengendalian yang kurang tepat pada saat tanaman padi terserang hama dan penyakit [5]. Hal ini mengakibatkan petani kita kehilangan hasil panen akibat serangan hama yang diperkirakan mencapai 200.000-300.000 ton per tahun.

Dengan perkembangan teknologi informasi dan komputer memungkinkan untuk mengidentifikasi penyakit dengan memanfaatkan Artificial Intelligence salah satunya dengan menggunakan metode pengenalan berbasis pengolahan citra dan teknologi pengenalan pola. Lingkup Artificial Intelligence telah mengalami perkembangan yang pesat dari ke tahun terkait dengan pengembangan penerapan Machine Learning, yang mengarah kepada munculnya pendalaman ilmu baru yaitu Deep Learning [6]. Metode Deep Learning dinilai lebih unggul jika dibandingkan metode konvensional dalam Machine learning [7]. Salah satu algoritma yang populer dalam Deep Learning adalah Convolutional Neural Network (CNN). Kini CNN dinilai telah menunjukkan keunggulan luar biasa dalam berbagai penerapan di dunia nyata dibandingkan sebagian besar pendekatan pada metode Machine Learning yang lain [8]-[11].

Model CNN adalah jaringan saraf multilayer yang terdiri atas 2 bagian: feature extractor dan trainable classifier, dimana feature extraction terdiri atas lapisan feature map dan bagian pengambilan fitur yang berbeda dari gambar mentah yaitu: penyaringan konvolusi dan downsampling. Filter konvolusi dapat dilihat sebagai feature extractor lokal yang digunakan untuk mengidentifikasi hubungan penelitian mencantumkan mengenai efektivitas kinerja CNN [8]. Sebagaimana yang diungkapkan [9] mengenai keunggulan Deep Learning dengan algoritma $\mathrm{CNN}$ dalam proses identifikasi dan pengenalan penyakit padi dan hama menggunakan CNN hasil eksperimen menunjukkan bahwa arsitektur CNN yang diusulkan mampu mencapai akurasi yang diinginkan sebesar 93,3\% dengan ukuran model $99 \%$ lebih sederhana jika dibandingkan dengan pretrained model VGG dan pada penelitian [10] dalam
Penelitian berikutnya membuktikan efektivitas kinerja CNN melalui identifikasi penyakit tanaman otomatis melalui objek citra, dimana pada hasil percobaannya menunjukkan angka akurasi yang cukup tinggi untuk pengenalan penyakit pada daun tanaman yaitu untuk akurasi validasi sebesar 91,83\% pada dataset publik [11]. Bahkan dalam kondisi background yang kompleks, akurasi rata-rata mencapai $92,00 \%$ untuk kelas prediksi objek penyakit padi dari data yang terkumpul. Putra dan rekannya juga menyatakan bahwa perkembangan terkini dalam jaringan saraf konvolusional berbasis pembelajaran dalam (CNN) cukup baik dalam meningkatkan akurasi klasifikasi citra [9]. Dimotivasi oleh keberhasilan CNN dalam klasifikasi citra, dengan memanfaatkan arsitektur dari VGG16 dan Inception V3, didapatkan hasil penelitian nilai akurasi yang diinginkan mencapai angka 93,3\% dengan ukuran model yang berkurang secara signifikan.

Sedangkan dalam konteks deteksi penyakit padi, terdapat salah satu penelitian yang cukup relevan dilakukan oleh Saptono and Doewes yaitu mengidentifikasi hama dengan memanfaatkan masukan gejala berupa teks dari petani, yang kemudian akan diidentifikasi menggunakan algoritma Jaro-Winkler Distance [5]. Memanfaatkan vektor ciri - ciri penyakit atau hama tanaman dengan melihat gejala fisik yang ada, proses deteksi dini hama dan penyakit tanaman padi menggunakan metode kemiripan cosinus (cosine similarity), kemudian masukan dari pengguna akan diperbaiki dengan kombinasi fitur auto-complete dan algoritma Jaro-Winkler Distance. Hasil dari identifikasi tersebut yaitu menampilkan penyakit dan hama tanaman padi dengan mengambil hasil tertinggi dari nilai kemiripan yang paling akurat. Berdasarkan beberapa hasil penelitian diatas, dibutuhkan model machine learning yang dapat memberikan nilai akurasi klasifikasi yang lebih tinggi.

Penelitian [12] yang membahas deteksi dan klasifikasi penyakit tanaman padi, dimana pada penelitian tersebut menggunakan 3 jenis penyakit tanaman padi, diantaranya: Bacterial Leaf Blight, Brown Spot, dan Leaf Smut, yang mana citra dari penyakit diatas didapat dengan memotret menggunakan kamera digital, mengusulkan pengelompokan K-means berbasis centroid feeding untuk melakukan segmentasi penyakit daun padi. Kemudian dilakukan penghapusan piksel berwarna hijau dibagian penyakit tanaman padi untuk meningkatkan output pengelompokan $K$-means. Fitur yang diekstrak berupa: warna, bentuk, dan tekstur. Algoritma yang digunakan untuk melakukan klasifikasi yaitu menggunakan Support Vector Machine (SVM) yang mampu mencapai accuracy $93,33 \%$ pada data latih dan $73,33 \%$ pada data validasi. 
Klasifikasi penyakit daun padi juga dilakukan oleh [13] menjadi data latih dan data validasi, dilanjutkan dengan menggunakan teknik machine learning didapatkan proses augmentasi (Augmentation) citra. Selesai proses accuracy lebih tinggi. Penyakit daun padi yang augmentasi, berikutnya adalah proses pembuatan dan diklasifikasi terdiri atas 3 kelas, diantaranya: leaf smut, pelatihan model yang kemudian diakhiri dengan proses bacterial leaf blight, dan brown spot masing-masing evaluasi model. Proses augmentasi diterapkan pada terdiri atas 40 gambar. Sebelum dilakukan pelatihan penelitian ini dengan tujuan untuk memaksimalkan terlebih dahulu dilakukan preprocessing dataset, dimana informasi pada data latih dengan cara menghasilkan data salah satunya yaitu dilakukan oversampling latih baru dan menerapkan penyamarataan model, menggunakan teknik augmentasi, dengan hasil akhir sehingga model mampu mengenali citra di berbagai dataset sebesar 480 gambar. Kemudian dilakukan split kondisi yang berbeda [9].

dengan rasio $90 \%$ data latih dan $10 \%$ data uji. Setelah

preprocessing dataset, dilakukan pelatihan model

\subsection{Dataset}

dengan beberapa algoritma diantaranya: KNN ( $K$ - Dataset yang digunakan dalam penelitian ini didapatkan Nearest Neighbour), J48 (Decision Tree), Nä̈ve Bayes, dari situs repositori terbuka bernama UCI Machine dan Logistic Regression. Dimana accuracy terbaik Learning Repository dengan judul data Rice Leaf dicapai oleh algoritma Decision Tree setelah 10-fold Diseases Data Set. Data terdiri atas tiga kelas yaitu cross validation, dengan accuracy sebesar $97 \%$ pada Bacterial leaf blight, Brown spot, dan Leaf smut yang data uji.

masing-masing berjumlah 40 data dengan total data 120

Kontribusi dan tujuan dari penelitian ini adalah membuat model Machine Learning dengan menerapkan arsitektur model dari Resnet101 ditambah dengan arsitektur rancangan yang diusulkan untuk pengklasifikasian penyakit pada tanaman padi berdasarkan citra kondisi daun padi sehingga tidak diperlukan proses inputasi secara manual mengenai gejala-gejala padi. Hal tersebut dilakukan untuk mendapatkan lama waktu proses klasifikasi yang lebih singkat dengan akurasi yang lebih tinggi dari penelitian sebelumnya serta diharapkan dapat mampu melakukan proses klasifikasi penyakit daun padi dengan lebih efektif.

\section{Metode Penelitian}

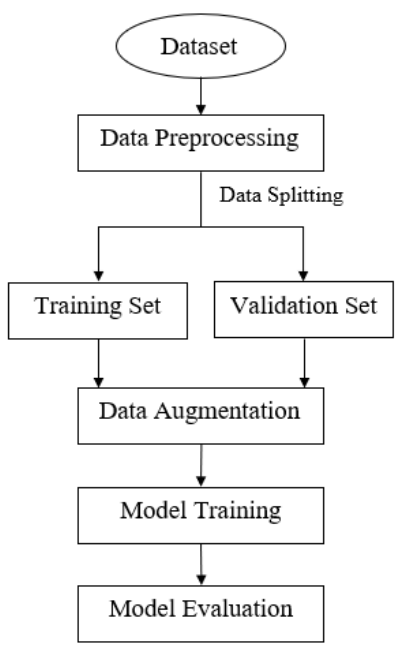

Gambar 1. Metode Penelitian untuk ketiga kelas. Grafik distribusi data pada setiap kelas dapat dilihat pada Gambar 2. Gambar 3 menunjukkan satu sampel data dari setiap kelas.

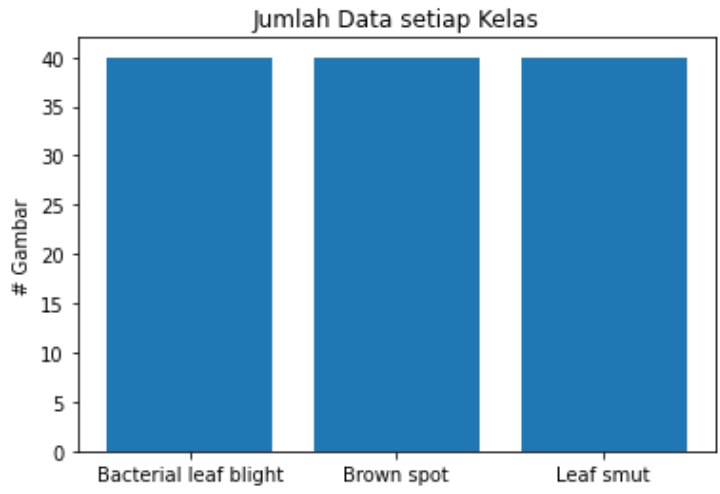

Gambar 2. Grafik distribusi data setiap kelas
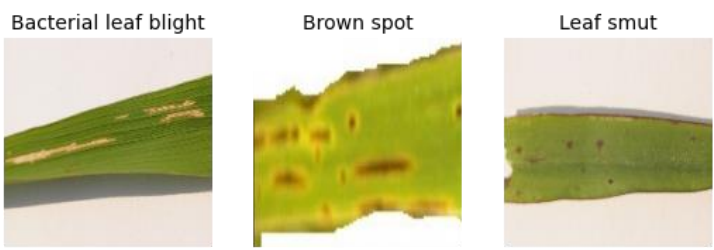

Gambar 3. Sampel data setiap kelas

\subsection{Arsitektur Model}

Penelitian ini menerapkan metode transfer learning dalam pembuatan model. Model siap pakai atau pretrained model yang akan digunakan adalah model ResNet101 yang kemudian akan ditambah dengan arsitektur layers baru pada bagian Fully Connected Layer. Gambar 4 menunjukkan arsitektur model beserta layers yang diusulkan. Layers tersebut diantaranya adalah: (1) Dense Layer 512 dengan activation 'relu', (2) BatchNormalization layer, (3) Dropout layer sebesar 0.7, (4) Dropout layer sebesar 0.7, (5) Dense Layer 64

DOI: https://doi.org/10.29207/resti.v5i6.3607

Creative Commons Attribution 4.0 International License (CC BY 4.0) 
dengan activation 'relu', (6) BatchNormalization layer, categorical_crossentropy untuk menerapkan teknik (7) Dropout layer sebesar 0.3, (8) Dropout layer sebesar meminimalisir loss dan meningkatkan akurasi model 0.3, dan diakhiri dengan (9) Dense layer dengan output [15]. terdiri atas 3 kelas dengan activation 'softmax'.

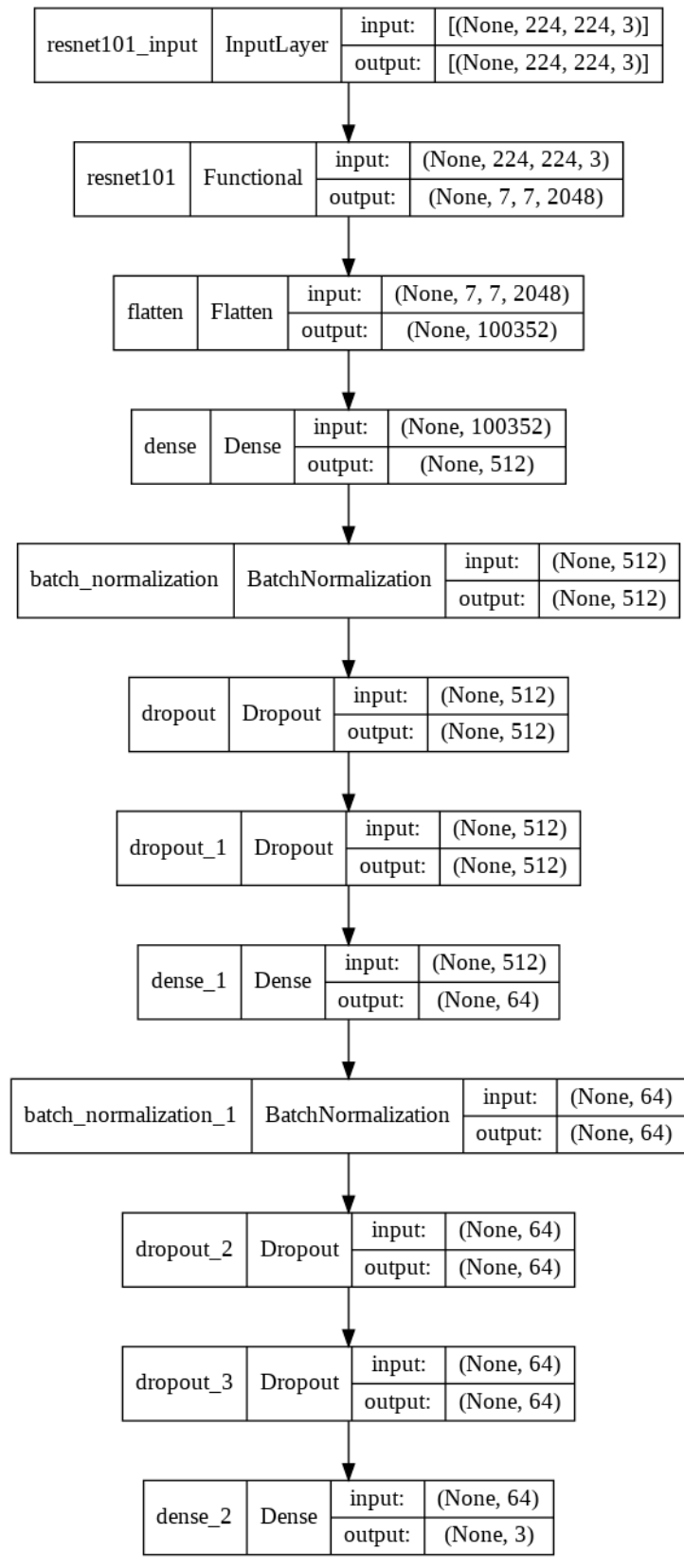

Gambar 4. Arsitektur model yang diusulkan

\subsection{Augmentasi Data}

Proses augmentasi berfungsi untuk menambah variansi citra sehingga dapat membantu meningkatkan nilai akurasi model [16]. Parameter augmentasi yang digunakan dalam penelitian ini adalah preprocessing_function dengan nilainya berasal dari library yang disediakan oleh Tensorflow yaitu tensorflow-keras-applications-resnet, rotation_range dengan nilai 30 , zoom_range dengan nilai 0,4 , dan terakhir horizontal_flip dengan nilai True.

\subsection{Skenario Pengujian}

Kelas citra untuk diklasifikasikan dalam penelitian ini berjumlah 3 kelas, yaitu Bacterial leaf blight, Brown spot, dan Leaf smut. Jumlah dari data yang digunakan dalam penelitian pada setiap kelas masing-masing berjumlah 40 .

Data kemudian dibagi (splitting) menjadi 2 bagian, yaitu data latih (train) dan data validasi (validation) dengan rasio pembagian pada masing-masing data sebesar $90 \%$ dan $10 \%$, yang akan digunakan untuk pelatihan dan pengujian model. Tabel 1 menunjukkan hasil dari pembagian data, dengan data train berjumlah 303 dan data validation berjumlah 76 .

Tabel 1. Tabel Pembagian Dataset

\begin{tabular}{ll}
\hline Bagian & Jumlah Data \\
\hline Data Latih & 108 \\
Data Validasi & 12 \\
\hline
\end{tabular}

Penelitian ini menerapkan 2 fungsi callback yang diterapkan pada proses pelatihan model. Callback pertama berfungsi untuk memantau nilai dari metrik val_loss selama iterasi pelatihan (epoch) model dengan memanfaatkan Early Stopping dan yang kedua berfungsi untuk menyimpan model selesai setiap iterasi pelatihan jika matrik val_accuracy mengalami peningkatan. Callback dan Early Stopping adalah dua metode yang disediakan oleh FastAI untuk melakukan pelacakan ketika pelatihan dan memantau nilai metrik loss validation dengan learning rate yang telah ditentukan, dengan menggunakan Early Stopping dapat mencegah terjadinya overfitting [17], [18].

\section{Hasil dan Pembahasan}

Batch Normalization diterapkan untuk memaksimalkan
pelatihan dan meminimalisir kemungkinan terjadinya overfitting [14]. Sementara penggunaan dropout telah terbukti dapat meningkatkan akurasi dan juga dapa membantu menghindari terjadinya overfitting pada penelitian [9]. Optimizer yang digunakan adalah adam,

Tahapan ini merupakan tahapan untuk mendapatkan hasil dari arsitektur model yang telah dibangun pada penelitian ini dalam kasus klasifikasi penyakit pada daun padi.

Optimizer 'adam' merupakan salah satu teknik optimizer Langkah pertama yang dilakukan adalah mendapatkan yang digunakan untuk memperbarui bobot pada model data dari situs yang telah disebutkan pada bagian metode [9]. Sedangkan, fungsi loss yang digunakan adalah penelitian dan kemudian dilakukan proses pembagian

DOI: https://doi.org/10.29207/resti.v5i6.3607

Creative Commons Attribution 4.0 International License (CC BY 4.0) 
(splitting) data menjadi 2 bagian, dengan rasio pembagian data latih (train) dan data validasi (validation) masing-masing sebesar $90 \%$ dan $2=10 \%$, sehingga jumlah dari data latih dan data validasi masingmasing berjumlah 108 data dan 12 data seperti yang telah ditunjukkan pada Tabel 1.

Dilanjutkan dengan proses augmentasi (augmentation), yang diberlakukan pada baik data latih. Parameter yang digunakan pada proses augmentasi adalah preprocessing_function dengan nilai berupa fungsi preprocess_input dari library Tensorflow modul keras application - resnet, rotation_range $=30$, zoom_range $=0,4$, dan horizontal_flip $=$ True . Augmentasi untuk data validasi sedikit berbeda dari data latih, dengan perbedaannya yang terletak pada parameter yang digunakan hanya parameter preprocessing_function dengan nilai yang sama dengan augmentasi data latih. Diberlakukan juga proses perubahan ukuran (resize) pada data latih dan data validasi menjadi 224 x 224

Berikutnya dibuat 2 fungsi callback yang akan diterapkan pada proses pelatihan model. Callback pertama menggunakan fungsi EarlyStopping dari library Tensorflow pada modul keras - callbacks, difungsikan untuk menghentikan proses pelatihan model apabila nilai pada metrik val_loss tidak mengalami perubahan selama 5 iterasi pelatihan model. Callback kedua memanfaatkan fungsi ModelCheckpoint, dari library yang sama seperti pada callback pertama, diterapkan untuk menyimpan model menjadi file dengan ekstensi $h 5$ pada setiap iterasi pelatihan jika matrik val_accuracy mengalami peningkatan selama proses iterasi pelatihan model. Model kemudian dilatih dengan 100 iterasi pelatihan (epoch) dan tidak lupa menerapkan kedua callback di atas.

Gambar 5 menunujukkan grafik akurasi pelatihan (training accuracy) dan akurasi validasi (validation accuracy) yang didapat setelah selesai proses iterasi pelatihan. Nilai pada sumbu $X$ menunjukkan jumlah iterasi pelatihan yang telah dijalani selama proses pelatihan model. Sedangkan nilai pada sumbu Y menunjukkan nilai tingkat akurasi, yang berada pada rentang 0 sampai 1 . Tampak pada grafik tersebut nilai akurasi validasi tertinggi terdapat pada iterasi ke 51 sampai ke 100 dengan nilai akurasinya sebesar $100 \%$.

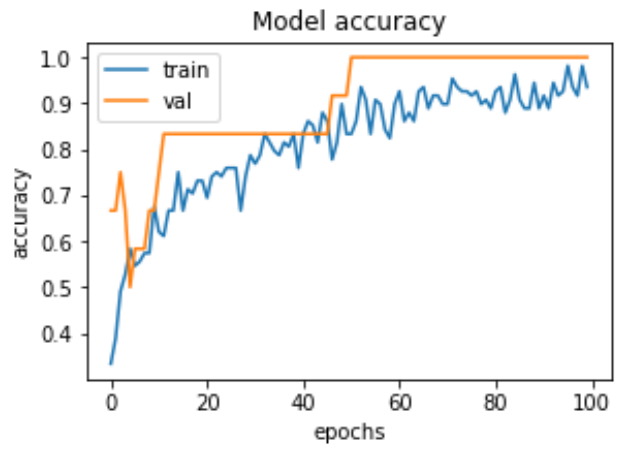

Gambar 5. Grafik accuracy model

Grafik loss pelatihan model digambarkan pada Gambar 6 dimana sumbu X menunjukkan iterasi pelatihan yang telah dijalani oleh model dan sumbu Y menunjukkan nilai loss model selama pelatihan dengan rentang nilai 0 sampai 2,2. Didapati pada grafik tersebut nilai validasi loss pada iterasi ke 100 sebesar 5,61\%.

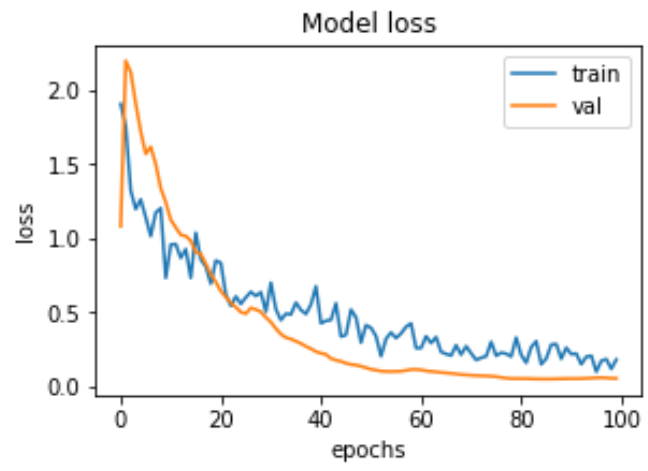

Gambar 6. Grafik loss model

Selanjutnya, evaluasi terhadap model juga dapat dilihat melalui tabel confusion matrix untuk mengukur kinerja metode pembelajaran mesin dalam mengetahui seberapa banyak model mampu melakukan prediksi dengan benar dan salah dari total keseluruhan data [19]. Hasil confusion matriks dapat dilihat pada Gambar 7. Berdasarkan data test gambar yang digunakan, didapati bahwa dari masing-masing 12 buah data dengan kelas masing-masing Bacterial leaf blight, Brown spot, dan Leaf smut, semua memberikan hasil prediksi dengan tepat, sesuai dengan kelas asli dari data tersebut.

Hasil evaluasi menggunakan classification report dapat diamati pada Gambar 8. Tampak bahwa nilai akurasi model sebesar 1,00 berdasarkan dari nilai val_accuracy tertinggi pada saat proses iterasi pelatihan model. Akurasi adalah jumlah prediksi benar dari keseluruhan citra didalam dataset. Jika akurasi mendekati 1 dapat menjadi indikasi bahwa model memiliki performa yang bagus, dan 0 merepresentasikan sebaliknya [20]

DOI: https://doi.org/10.29207/resti.v5i6.3607

Creative Commons Attribution 4.0 International License (CC BY 4.0) 


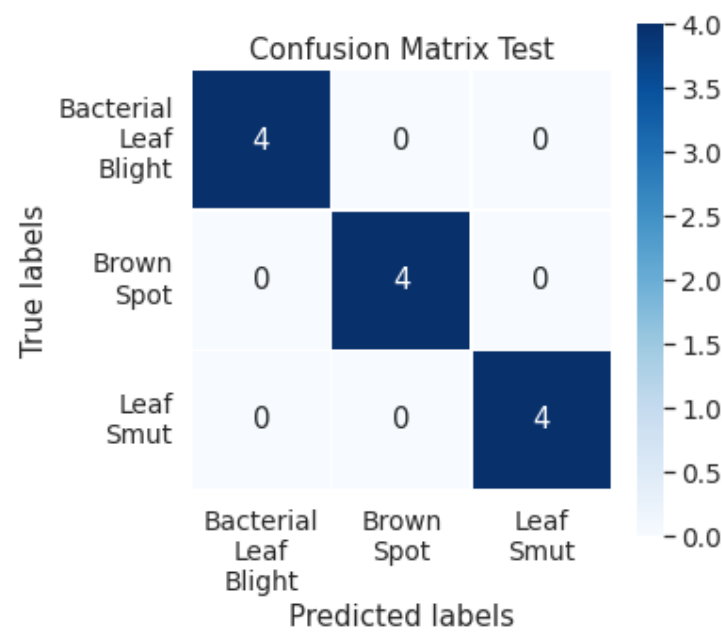

Gambar 7. Hasil Tabel Confusion Matrix

\begin{tabular}{rrrrr} 
& precision & recall & f1-score & support \\
Bacterial leaf blight & 1.00 & 1.00 & 1.00 & \\
Brown spot & 1.00 & 1.00 & 1.00 & \\
Leaf smut & 1.00 & 1.00 & 1.00 & \\
& & & & \\
accuracy & & & 1.00 & 12 \\
macro avg & 1.00 & 1.00 & 1.00 & 12 \\
weighted avg & 1.00 & 1.00 & 1.00 & 12 \\
\multicolumn{4}{c}{ Gambar 8. Classification Report } &
\end{tabular}

Selain akurasi juga terdapat precision, recall, dan $f 1$ score yang mampu mengukur performa model. Presicion adalah prediksi benar positif dibandingkan dengan keseluruhan hasil yang diprediksi positif, recall merupakan rasio prediksi benar positif dibandingkan dengan keseluruhan data yang benar positif, sedangkan fl-score merupakan perbandingan rata-rata precision dan recall yang dibobotkan [21]. Dimana dalam classification report dapat dilihat kelas Bacterial leaf blight, Brown spot, dan Leaf smut memberikan nilai precision, recall, dan fl-score yang sempurna, yaitu 1,00 .

\section{Kesimpulan}

Penggunaan metode Deep CNN dengan menggunakan pretrained model dari ResNet101 dan tambahan arsitektur pengusul pada bagian Fully Connected Layer dalam proses klasifikasi penyakit padi dengan hasil performa accuracy pada classification report sebesar [8] $100 \%$ dengan data validasi, dengan nilai validation loss rendah yaitu 5,61\%. Peningkatan tersebut disebabkan oleh implementasi ResNet101 yang optimal serta penambahan layer arsitektur dari penulis berupa: (1) Dense Layer 512 dengan activation 'relu', (2) BatchNormalization layer, (3) Dropout layer sebesar 0.7, (4) Dropout layer sebesar 0.7, (5) Dense Layer 64 dengan activation 'relu', (6) BatchNormalization layer, (7) Dropout layer sebesar 0.3, (8) Dropout layer sebesar 0.3 , dan diakhiri dengan (9) Dense layer dengan output terdiri atas 3 kelas dengan activation 'softmax'. Sehingga, dengan penggunaan metode tersebut penelitian-penelitian yang sebelumnya menggunakan dataset serupa dapat ditingkatkan performa accuracy sebesar 3\% hingga 7\% dan mampu membantu mempersingkat waktu karena tidak melakukan inputan gejala secara manual melainkan menggunakan citra untuk klasifikasi penyakit. Penelitian kedepannya disarankan untuk menggunakan jumlah kelas dan dataset yang lebih banyak sehingga klasifikasi jenis padi semakin bervariasi sesuai dengan perkembangan penyakit padi kedepannya. Selain hal tersebut, dalam membuat model disarankan mencoba menggunakan metode yang lebih bervariasi seperti menerapkan metode ensemble learning yang dapat meningkatkan optimasi model.

\section{Ucapan Terimakasih}

Terima Kasih kepada KEMENDIKBUD RISTEKDIKTI yang telah memberikan pendanaan sepenuhnya terhadap penelitian ini melalui program Program Kreativitas Mahasiswa (PKM) Tahun 2021.

\section{Daftar Rujukan}

[1] E. Anggiratih, S. Siswanti, S. K. Octaviani, and A. Sari, "Klasifikasi Penyakit Tanaman Padi Menggunakan Model Deep Learning Efficientnet B3 dengan Transfer Learning," $J$. Ilm. SINUS, vol. 19, no. 1, p. 75, 2021, doi: 10.30646/sinus.v19i1.526.

[2] A. Purnamawati, W. Nugroho, D. Putri, and W. Hidayat, "Deteksi Penyakit Daun Pada Tanaman Padi Menggunakan Algoritma Decision Tree, Random Forest , Naïve Bayes , Svm Dan Knn," Info Tekjar J. Nas. Inform. dan Teknol. Jar., vol. 5, no. 1, pp. 212-215, 2020.

3] J. Kusanti, K. Penyakit, D. Padi, and A. Haris, "Klasifikasi Penyakit Daun Padi Berdasarkan Hasil Ekstraksi Fitur GLCM Interval 4 Sudut," J. Inform. J. Pengemb. IT, vol. 03, no. 01, pp. $1-6,2018$.

[4] BPS, "Prediksi Padi Menurut Kabupaten Kota di Jawa Timur," Badan Pusat Statistik Provinsi Jawa Timur, 2018. .

[5] R. Saptono and A. Doewes, "Deteksi dini hama dan penyakit tanaman padi memanfaatkan masukan tekstual dengan metode cosine similarity," Semin. Ilm. Ilmu Komput., no. September 2018, pp. 1-16, 2014.

[6] Y. Lecun, Y. Bengio, and G. Hinton, "Deep learning," Nature, vol. 521, no. 7553, pp. 436-444, 2015, doi: 10.1038/nature14539.

7] M. Z. Alom et al., "A state-of-the-art survey on deep learning theory and architectures," Electron., vol. 8, no. 3, 2019, doi: 10.3390/electronics8030292.

W. jie Liang, H. Zhang, G. feng Zhang, and H. xin Cao, "Rice Blast Disease Recognition Using a Deep Convolutional Neural Network," Sci. Rep., vol. 9, no. 1, pp. 1-10, 2019, doi: 10.1038/s41598-019-38966-0.

[9] C. R. Rahman et al., "Identification and recognition of rice diseases and pests using convolutional neural networks," Biosyst. Eng., vol. 194, pp. 112-120, 2020, doi: 10.1016/j.biosystemseng.2020.03.020.

[10] M. A. Islam, N. Rahman Shuvo, M. Shamsojjaman, S. Hasan, S. Hossain, and T. Khatun, "An Automated Convolutional Neural Network Based Approach for Paddy Leaf Disease Detection," Int. J. Adv. Comput. Sci. Appl., vol. 12, no. 1, pp. 280-288, 2021, doi: 10.14569/IJACSA.2021.0120134.

[11] J. Chen, J. Chen, D. Zhang, Y. Sun, and Y. A. Nanehkaran, "Using deep transfer learning for image-based plant disease identification," Comput. Electron. Agric., vol. 173, no. 
November 2019, p. $\quad 105393$ 2020 doi: [17] A. Chakraborty, D. Kumer, and K. Deeba, "Plant Leaf Disease 10.1016/j.compag.2020.105393.

[12] H. B. Prajapati, J. P. Shah, and V. K. Dabhi, "Detection and classification of rice plant diseases," Intell. Decis. Technol., vol. 11, no. 3, pp. 357-373, 2017, doi: 10.3233/IDT-170301.

[13] K. Ahmed, T. R. Shahidi, S. M. Irfanul Alam, and S. Momen, "Rice Leaf Disease Detection Using Machine Learning Techniques," in 2019 International Conference on Sustainable Technologies for Industry 4.0 (STI), Dec. 2019, vol. 58, pp. 15, doi: 10.1109/STI47673.2019.9068096.

[14] K. Thenmozhi and U. Srinivasulu Reddy, "Crop pest classification based on deep convolutional neural network and transfer learning," Comput. Electron. Agric., vol. 164, no. June, p. 104906, 2019, doi: 10.1016/j.compag.2019.104906.

[15] M. K. Priya and S. Dhanabal, "Analyses of Nine Different Types of Diseases in Paddy with Hybrid Algorithms using Deep Learning," vol. 8, no. 08, pp. 1-7, 2020.

[16] R. Jain, P. Nagrath, G. Kataria, V. Sirish Kaushik, and D. Jude Hemanth, "Pneumonia detection in chest X-ray images using convolutional neural networks and transfer learning," Meas. J. Int. Meas. Confed., vol. 165, p. 108046, 2020, doi: 10.1016/j.measurement.2020.108046. Recognition Using Fastai Image Classification," Proc. - 5th Int. Conf. Comput. Methodol. Commun. ICCMC 2021, no. Iccmc, pp. 1624-1630, 2021, doi: 10.1109/ICCMC51019.2021.9418042.

[18] L. W. Liu, S. H. Hsieh, S. J. Lin, Y. M. Wang, and W. S. Lin, "Rice blast (Magnaporthe oryzae) occurrence prediction and the key factor sensitivity analysis by machine learning," Agronomy, vol. 11, no. 4, pp. 1-15, 2021, doi: 10.3390/agronomy11040771

[19] M. Koklu, I. Cinar, and Y. S. Taspinar, "Classification of rice varieties with deep learning methods," Comput. Electron. Agric., vol. 187, no. June, p. 106285, 2021, doi: 10.1016/j.compag.2021.106285.

[20] S. Ramesh and D. Vydeki, "Application of machine learning in detection of blast disease in south indian rice crops," J. Phytol., vol. 11, pp. 31-37, 2019, doi: 10.25081/jp.2019.v11.5476.

[21] A. Sagar and J. Dheeba, "On using transfer learning for plant disease detection," bioRxiv, 2020, doi: 10.1101/2020.05.22.110957. 